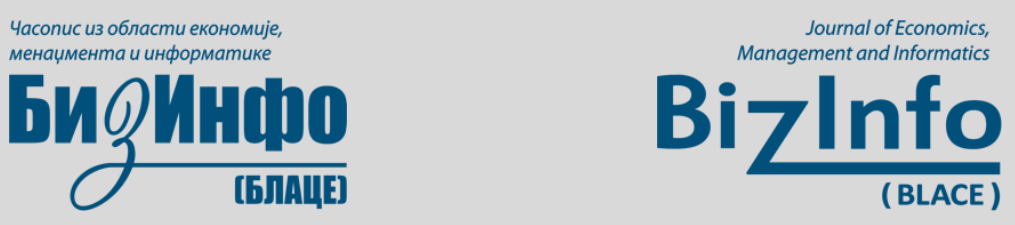

Прегледни рад/ Review paper

УДК/UDC: 338.48-52:796.352(497.5)

https://doi.org/10.5937/bizinfo2002047A

\title{
Perspective of development of golf tourism in Croatia
}

\section{Perspektiva razvoja golf turizma u Hrvatskoj}

\author{
Romina Alkier ${ }^{\mathrm{a}}$, Tonći Jerak ${ }^{\mathrm{b}}$, Vedran Milojica ${ }^{\mathrm{a} *}$ \\ ${ }^{a}$ University of Rijeka, Faculty of Tourism and Hospitality Management Opatija, Croatia \\ ${ }^{\mathrm{b}}$ University of Zadar, Centre for Physical Exercise and Student Sport, Croatia
}

\begin{abstract}
Golf tourism represents an important part of a sports tourism offer of a destination. In the last couple of decades, it has been registering growth on European and world level. Golfers are characterized as tourists with high purchasing power which was an additional stimulus for tourist destinations to invest in developing golf tourism, in order to attract a large number of golf players, and that way increase the tourist turnover with particular emphasis on tourist consumption. The primary aim of this paper was to present the current state of golf tourism offer in Europe, as well as the state of golf tourism in the Republic of Croatia, as a European Union member with the use of data from secondary sources. Based on the findings the authors presented the developmental activities.
\end{abstract}

Keywords: golf, golf tourism, tourist offer, Croatia, Europe

Sažetak: Golf turizam predstavlja važan dio ponude sportskog turizma destinacije. $U$ posljednjih nekoliko desetljeća bilježi rast na europskoj $i$ svjetskoj razini. Golferi su okarakterizirani kao turisti s visokom kupovnom moći, što je bio dodatni poticaj turističkim odredištima da ulažu u razvoj golf turizma, kako bi privukli velik broj igrača, te na taj način povećali turistički promet s posebnim naglaskom na turističku potrošnju. Primarni cilj ovog rada bio je predstaviti trenutno stanje ponude golf turizma u Europi, kao i stanje golf turizma u Republici Hrvatskoj, kao članici Europske unije, koristeći podatke iz sekundarnih izvora. Na temelju nalaza autori su predstavili razvojne aktivnosti.

Ključne reči: golf, golf turizam, turistička ponuda, Hrvatska, Europa

\section{Introduction}

Frequent changes on the international tourism market and more expressed competition requires constant innovation of tourist facilities which will provide greater

${ }^{*}$ Corresponding author

E-mail address: vedran.milojica@gmail.com

${ }^{1} \mathrm{PhD}$ student at Faculty of Tourism and Hospitality Management Opatija, University of Rijeka

This is an open access paper under the license (c) (1) () 
recognizability for a destination and separate it from the majority. Bearing in mind growing trend of taking care of own health through nutrition and sports activities, it is quite understandable that tourists will search for facilities which will make their stay in a destination more active. This has led to forming a special tourism segment called Sports Tourism. This specific form of tourism combines various forms of vacation, from the ones that are relaxing and therapeutic to the ones that of sports competitive and extravagant, which contain active and adventure forms with a high level of sports activities in which tourists are getting included. In addition to raising the quality of holiday tourism and shaping specific forms of tourism in accordance with the resource base, Republic of Croatia is trying to improve its position and achieve competitive advantage on the tourist market, which also implies development of sports tourism, for which the Republic of Croatia has all the preconditions. In such an orientation of development, golf has a special place, which is evolving from an elite sport into a sport accessible to an increasing number of people and is becoming a motivating factor in one segment of the tourist market. Competitive tourism destinations have proven that successful development of golf tourism can most definitely contribute to achieving higher level of quality of a destination's tourist product as well as achieving competitiveness on the tourist market. The purpose of this paper is to determine the potential of successful development of Golf tourism in the Republic of Croatia and propose the developmental actions. Also, the authors will present the examples of good practice of European golf tourism destinations.

\section{Golf as a part of a contemporary tourist product-an insight into theoretical ind international characteristics}

In the last couple of decades of the last, and the beginning of this century were marked with significant changes in tourist demand, all because of growth of additional funds, life standard, and growth of free time intended for a holiday and recreation, and tendency to return to nature and traditional values. As a result of that, a significant increase of interest for specific forms of tourism was registered, considering that their very content can satisfy the specific needs of demanding tourists for high quality and diverse tourist product. One of them is Sports tourism. Modern tourists are constantly engaged in business activities and frequently experience stress which resulted in them being less physically active. As a result of that, an increase was registered when searching holidays motivated by physical activity and sports. Sports has a significant contribution in development of tourism in destinations not only in terms of economic effects, but also in the sense of urban regeneration, improvement of infrastructure, enrichment of tourist offer and strengthening of destination's image (Ivanović et al., 2020; Alkier et al., 2015; Rabotić, 2011, p. 155). One of the elements of sports tourism offer that has registered a significant growth, and still is, is golf tourism, which is the main topic of this paper.

Golf represents an outdoor sports activity aimed in putting a small ball with sticks of different characteristics from the point where the starting hit is made to the holes throughout towards the end of the golf court which is covered with grass, located near the water, sand and similar artificial obstacles as well as natural obstacles. Throughout the years golf became a sport branch which is preferred by many people in the world due to its leisure time activities; players of all age groups are enabled to experience 
the sense of freedom and calmness, there is no requirement of excessive physical force, and players compete against the field and themselves rather than against the opponent (Çuhadar, 2013, p. 1620). Observation of current trends in contemporary tourism flows indicates that travels motivated by playing golf represent a significant part of emissive tourist market (Bartoluci \&Jerkunica, 2019) on European level which is also in accordance with the findings of Jeremić et al. (2010) who also emphasize in their work high level of development, prevalence as well as popularity of golf in the tourist offer of developed countries due to which it began to take a significant place in today's tourism.

This is confirmed by many research which study golf tourism from various points of view, i.e. determining the level of satisfaction (Moital et al., 2013) and loyalty to the destination (Thanh et al., 2021), determining the developmental directions of golf tourism (Ersoy \& Gülmez, 2014), determining the relationship between place attachment, golf tourism destination image, and revisit intention of golf tourists (Song et al., 2017), determining the profile of tourists and security perceptions of a destination (Aksu et al., 2016), observing the development of golf tourism from a sustainable point of view (López-Bonilla \& López-Bonilla, 2016; López-Bonilla et al., 2018; Domínguez-Gómez and González-Gómez, 2017; Boukas \& Ziakas, 2014), and many others. Research like these enable for golf tourism developers to rethink in which direction precisely they should focus when rethinking (golf) tourist offer development.

Those destinations that wish to become more recognized as golf tourism destinations, who wish to achieve growth and development on the international tourist market need to conduct significant investments in golf infrastructure as well as golf projects. Also, a tourist destination needs to possess certain pre-conditions for development of golf tourism such as vicinity of large emissive markets, natural beauties and mild climate that enables players to visit a golf tourist destination throughout the entire year.

It is a known fact that for many years Europe has remained the leading world region in achieving tourist arrivals (710 million, $+5 \%$ in relation to the previous year) and tourist receipts (570 billion US dollars, $+5 \%$ ) (UNWTO, 2019). It can be justifiably assumed that this positive trend of growth is a result of constant efforts in tourist offer improvement and offering tourist products and services capable of satisfying specific needs and wishes of demanding tourists, one of them being the desire to play golf. European destinations became rather quickly aware of the potential of development of golf and started investing in its development on country level. The question is: which is the current stage of its development? In order to determine this, following in this chapter the authors will present the current state of golf industry with the use of quantitative indicators on world level, and later following they will focus on the European level.

Table 1. Global golf score card

\begin{tabular}{cc}
\hline Land area & $147,553,000 \mathrm{~km} 2 / 56,970,000$ miles $^{2}$ \\
\hline Countries & 249 \\
Golfing countries & 209 \\
Golf courses & 38,864
\end{tabular}


Golf holes

556,176

Golf facilities

32,471

534

9,576

29,288

Publicly accessible courses

Population

Population per golf hole

$7,632,819,325$

13,724

Source: R\&A. (2019). Golf Around the World. Edition 3, p. 5, available at https://www.randa.org/ /media/files/golfdevelopment/gaw-2019-edition-3-hi.ashx

The data in the previous table clearly indicate a strong development of golf considering that it is present in 209 world countries. So far 32,471 golf facilities were built, as well as 38,864 golf courses with 556,176 golf holes, 9,576 private and 29,288 publicly accessible courses.

Table 2. New golf courses under development

\begin{tabular}{ccccc}
\hline Region & In planning & $\begin{array}{c}\text { Under } \\
\text { construction }\end{array}$ & $\begin{array}{c}\text { Total courses } \\
\text { under } \\
\text { development }\end{array}$ & $\begin{array}{c}\text { \% new } \\
\text { development }\end{array}$ \\
\hline Africa & 35 & 21 & 56 & $10 \%$ \\
Asia & 86 & 63 & 149 & $28 \%$ \\
Europe & $\mathbf{1 0 3}$ & $\mathbf{4 8}$ & $\mathbf{1 5 1}$ & $\mathbf{2 8 \%}$ \\
North & 84 & 49 & 133 & $25 \%$ \\
America & 18 & 8 & 26 & $5 \%$ \\
Oceania & 10 & 9 & 19 & $4 \%$ \\
South & $\mathbf{3 3 6}$ & $\mathbf{1 9 8}$ & $\mathbf{5 3 4}$ & $\mathbf{1 0 0 \%}$ \\
America & The World & &
\end{tabular}

Source: R\&A. (2019). Golf Around the World. Edition 3, p. 6, available at https://www.randa.org/ /media/files/golfdevelopment/gaw-2019-edition-3-hi.ashx

The data in the previous table state that on world level currently there are 534 golf courses that are in the process of under development, of which 336 are being planned, and 198 are under construction. The majority is in Europe (151), after which follow Asia (149), North America (133), Africa (56), Oceania (26), and South America (19).

Table 3. New golf courses opened 2014-2018

\begin{tabular}{cccccccc}
\hline & 2014 & 2015 & 2016 & 2017 & 2018 & Total & $\%$ \\
\hline Africa & 4 & 8 & 5 & 4 & 4 & 25 & $6 \%$ \\
Asia & 30 & 25 & 29 & 23 & 19 & 126 & $30 \%$ \\
Europe & $\mathbf{2 4}$ & $\mathbf{1 7}$ & $\mathbf{2 1}$ & $\mathbf{2 7}$ & $\mathbf{1 0}$ & $\mathbf{9 9}$ & $\mathbf{2 4 \%}$ \\
North America & 26 & 27 & 31 & 32 & 15 & 131 & $32 \%$ \\
Oceania & 5 & 6 & 3 & 1 & 0 & 15 & $4 \%$ \\
South America & 4 & 4 & 4 & 3 & 3 & 18 & $4 \%$ \\
The World & $\mathbf{9 3}$ & $\mathbf{8 7}$ & $\mathbf{9 3}$ & $\mathbf{9 0}$ & $\mathbf{5 1}$ & $\mathbf{4 1 4}$ & $\mathbf{1 0 0 \%}$ \\
\hline
\end{tabular}

Source: R\&A. (2019). Golf Around the World. Edition 3, p. 7, available at https://www.randa.org/ /media/files/golfdevelopment/gaw-2019-edition-3-hi.ashx

\footnotetext{
${ }^{1}$ As of 31 st October 2018
} 
In the period 2014-2018 the highest number of golf courses was opened in North America (131), followed by Asia (126), and Europe took third place with 99 opened golf courses.

Table 4. Europe golf score card

\begin{tabular}{cc}
\hline Land area & $9,938,000 \mathrm{~km} 2 / 3,837,000$ miles 2 \\
\hline Countries & 54 \\
Golfing countries & 44 \\
Golf courses & 8,940 \\
Golf holes & 125,268 \\
Golf facilities & 7,132 \\
Courses under development & 151 \\
Private courses & 1,263 \\
Publicly accessible courses & 7,677 \\
Population & $742,648,010$ \\
Population per golf hole & 5,928 \\
\hline
\end{tabular}

Source: R\&A. (2019). Golf Around the World. Edition 3, p. 13, available at https://www.randa.org/ /media/files/golfdevelopment/gaw-2019-edition-3-hi.ashx

European golf scorecard indicates that out of 54 European countries 44 are golfing countries. They are investing significantly in building golf infrastructure; currently there are 8,940 golf courses with 125,268 golf holes. Furthermore, 7,132 golf facilities were built, 1,263 private golf courses and 7,677 public golf courses. As previously mentioned, currently 151 golf courses are in process of development.

The following table represents the comparative analysis of registered golfers in 2018 in relation to the previous year.

Table 5. Number of registered golfers in Europe

\begin{tabular}{|c|c|c|c|c|c|}
\hline Country & $\begin{array}{c}\text { Registered } \\
\text { golfers } 2018\end{array}$ & $\begin{array}{c}\text { Registered } \\
\text { golfers } 2017\end{array}$ & $\begin{array}{c}2018 / 2017 \\
(\%)\end{array}$ & Status $^{3}$ & $\begin{array}{l}\text { Changes in the } \\
\text { number of golfers } \\
2017 \text { vs. } 2018\end{array}$ \\
\hline England & 645,151 & 655,839 & $-1,63 \%$ & $\downarrow$ & $-10,688$ \\
\hline Germany & 642,240 & 644,943 & $-0,42 \%$ & $=$ & $-2,703$ \\
\hline Sweden & 461,404 & 468,570 & $-1,53 \%$ & $\downarrow$ & $-7,166$ \\
\hline France & 412,726 & 410,171 & $0,62 \%$ & $=$ & 2,555 \\
\hline Netherlands & 396,299 & 387,597 & $2,25 \%$ & $\uparrow$ & 8,702 \\
\hline Spain & 269,470 & 270,464 & $-0,37 \%$ & $=$ & -994 \\
\hline Ireland & 182,398 & 183,461 & $-0,58 \%$ & $=$ & $-1,063$ \\
\hline Scotland & 180,281 & 187,802 & $-4,00 \%$ & $\downarrow$ & $-7,521$ \\
\hline Denmark & 149,044 & 151,243 & $-1,45 \%$ & $\downarrow$ & $-2,199$ \\
\hline Finland & 138,955 & 142,672 & $-2,61 \%$ & $\downarrow$ & $-3,717$ \\
\hline Austria & 108,733 & 102,695 & $5,88 \%$ & $\uparrow$ & 6,038 \\
\hline Norway & 103,000 & 100,702 & $2,28 \%$ & $\uparrow$ & 2,298 \\
\hline Italy & 91,165 & 90,173 & $1,10 \%$ & $\uparrow$ & 992 \\
\hline Switzerland & 89,236 & 91,785 & $-2,78 \%$ & $\downarrow$ & $-2,549$ \\
\hline Belgium & 65,028 & 64,965 & $0,10 \%$ & $=$ & 63 \\
\hline $\begin{array}{c}\text { Czech } \\
\text { Republic }\end{array}$ & 53,252 & 53,712 & $-0,86 \%$ & $=$ & -460 \\
\hline
\end{tabular}




\begin{tabular}{|c|c|c|c|c|c|}
\hline Wales & 42,743 & 44,551 & $-4,06 \%$ & $\downarrow$ & $-1,808$ \\
\hline Iceland & 17,164 & 17,024 & $0,82 \%$ & $=$ & 140 \\
\hline Portugal & 15,257 & 15,847 & $-3,72 \%$ & $\downarrow$ & -590 \\
\hline Slovakia & 7,780 & 8,689 & $-10,46 \%$ & $\downarrow$ & -909 \\
\hline Turkey & 7,083 & 6,776 & $4,53 \%$ & $\uparrow$ & 307 \\
\hline Poland & 5,678 & 5,646 & $0,57 \%$ & $=$ & 32 \\
\hline Slovenia & 4,500 & 8,762 & $-48,64 \%$ & $\downarrow$ & $-4,262$ \\
\hline Luxembourg & 3,392 & 3,487 & $-2,72 \%$ & $\downarrow$ & -95 \\
\hline Latvia & 3,000 & 2,800 & $7,14 \%$ & $\uparrow$ & 200 \\
\hline Estonia & 2,281 & 2,843 & $-19,77 \%$ & $\downarrow$ & -562 \\
\hline Russia $^{1}$ & 2,240 & 2,104 & $6,46 \%$ & $\uparrow$ & 136 \\
\hline Kazakhstan & 1500 & $\mathrm{n} / \mathrm{a}$ & $\mathrm{n} / \mathrm{a}$ & $\mathrm{n} / \mathrm{a}$ & $\mathrm{n} / \mathrm{a}$ \\
\hline Cyprus² & 1,394 & 1,399 & $-0,36 \%$ & $=$ & -5 \\
\hline Lithuania & 1,300 & 1,101 & $18,07 \%$ & $\uparrow$ & 199 \\
\hline Hungary & 1,137 & 1,279 & $-11,10 \%$ & $\downarrow$ & -142 \\
\hline Bulgaria & 936 & 912 & $2,63 \%$ & $\uparrow$ & 24 \\
\hline Croatia & 916 & 1,380 & $-33,62 \%$ & $\downarrow$ & -464 \\
\hline Romania $^{1}$ & 880 & 697 & $26,26 \%$ & $\uparrow$ & 183 \\
\hline Greece & 829 & 1,038 & $-20,13 \%$ & $\downarrow$ & -209 \\
\hline Malta & 788 & 555 & $41,98 \%$ & $=$ & 233 \\
\hline $\begin{array}{l}\text { Liechtenstei } \\
n^{2}\end{array}$ & 781 & 864 & $-9,61 \%$ & $\downarrow$ & -83 \\
\hline Israel $^{2}$ & 780 & 950 & $-17,89 \%$ & $\downarrow$ & -170 \\
\hline Serbia & 747 & 720 & $3,75 \%$ & $\uparrow$ & 27 \\
\hline Ukraine $^{12}$ & 536 & 516 & $3,88 \%$ & $\uparrow$ & 20 \\
\hline Andorra $^{2}$ & 330 & 221 & $49,32 \%$ & $\uparrow$ & 109 \\
\hline Moldova 2 & 182 & 185 & $-1,62 \%$ & $\downarrow$ & -3 \\
\hline Azerbaijan 12 & 104 & 104 & $0,00 \%$ & $=$ & 0 \\
\hline Armenia 1 & 60 & 120 & $-50,00 \%$ & $\downarrow$ & -60 \\
\hline Georgia $^{1}$ & 22 & 50 & $-56,00 \%$ & $\downarrow$ & -28 \\
\hline Macedonia & $\mathrm{n} / \mathrm{a}$ & 119 & $\mathrm{n} / \mathrm{a}$ & $\mathrm{n} / \mathrm{a}$ & $\mathrm{n} / \mathrm{a}$ \\
\hline Albania & $\mathrm{n} / \mathrm{a}$ & 64 & $\mathrm{n} / \mathrm{a}$ & $\mathrm{n} / \mathrm{a}$ & $\mathrm{n} / \mathrm{a}$ \\
\hline Total & $4.112,722$ & $4.137,597$ & $-0,59 \%$ & & -24396 \\
\hline
\end{tabular}

Source: KPMG (2019). Golf Participation Report for Europe 2019 Golf Advisory Practice in EMEA, https://www.golfbenchmark.com/golf_participation_report_for_europe_2019

Notes: Statistics for 2018 were not provided by the local golf associations in Albania, Belarus, Bosnia \& Herzegovina, Macedonia, Montenegro and San Marino. ${ }^{1}$ The participation rate is below $0.01 \%$. ${ }^{2}$ Data provided by the International Golf Federation. ${ }^{3}$ Status represents the level of change in registered golfers: $\uparrow$ indicates growth, $\downarrow$ indicates a decline, $=$ indicates stability $( \pm 1 \%$ change $)$.

Previous table presents the number of registered golfers for the years 2018 and 2017 in 47 European countries. Three countries (Kazakhstan, Macedonia and Albania) could not be taken into consideration due to the lack of data for comparison. When observing the changes in the number of registered golfers in 2018 in relation to the previous year, it has been determined that

growth was registered in 13 countries, highest being England, followed by Germany, Sweden, France, Netherlands, Spain, Ireland, Scotland, Denmark, Finland, Austria, etc. Some insignificant changes $( \pm 1 \%)$ were registered in 11 countries, and 20 
countries registered a decrease. However, among these 20 countries only 11 registered a decrease of $+5 \%$ (Slovakia, Slovenia, Estonia, Hungary, Croatia, Greece, Israel, Armenia and Georgia). Overview of previously presented information indicates a somewhat satisfactory situation.

To present more precisely the importance of golf for development of tourist destinations, following the authors will present the examples of good practice.

France (Golf Course Association Europe, n.d.) is a destination which offers its golf offer for tourists throughout the entire year. As such it has been considered as one of the best golf destinations in Europe, due to the richness of various golf courses, affordable prices, beautiful landscape and favourable weather conditions. In the last decade golf has registered a significant increase in France both in demand and supply. The observation of its supply indicates that approximately $70 \%$ of them are commercial courses, while $30 \%$ of them are owned by members. Over 100 French golf courses are being owned by multicourse entities (chains) and over 200 of them are affiliated to commercial networks. It has been registered France has over 400,000 officially registered golfers, of which $70 \%$ are male and $30 \%$ are female. Also, $11 \%$ of them are junior players. Besides registering a minor decrease of registered players in 2013, France has been registering a growing trend, and it is expected that this will continue in the future. France is clearly investing strongly in development of golf hoping to benefit from 60 million of tourists undertaking travels motivated by golf, and to become even more recognized as a golf tourism destination. According to YourGolfTravel (n.d.) holidays motivated by golf are very popular, and especially for travellers from the United Kingdom, not just due to the excellent golf courses, but also for the additional added value that France is offering. This destination has an excellent traffic connection, whether by aeroplane, railway or by car. In 2021 the visitors have declared the following French golf holidays as the best: Le Golf National in Paris, Najeti Hotel Du Parc and Le Touquet in Northern France, Golf du Medoc Resort in Bordeaux, and Terre Blanche Hotel Spa Golf Resort in French Riviera. Along with the excellent golf offer visitors can experience excellent gastronomic and oenological offer, see beautiful cultural and historical, as well as natural sights, and experience something unique and unrepeatable.

Portugal also belongs among the destinations with a tremendously developed golf tourist offer. It was declared as the best European Golf Destination in the period 20142019, and as the best world Golf destination between 2014-2018, due to the rich offer of golf courses capable of satisfying various profiles of golf players depending on different levels of game difficulty preferred and the available funds. Over ninety of varied golf courses were built on Portugal soil by famous architects. Among wellknown Portuguese destinations the most recognized are Algarve and Lisbon Coast when more experienced players are concerned. These two destinations are the hosts of numerous professional golf tours (visitPortugal, n.d.). Algarve has been considered as the best golf destination on world level by numerous magazines in the field of sports, as well as by the international associations of specialist tour operators specialized in golf, which clearly implies that its offer is of significantly high quality. Appropriate climate permits players to visit Algarve and play golf throughout the entire year. This region has almost four dozen-built golf courses, mostly located in 
protected areas with a beautiful landscape. These courses became widely recognized for the quality and diversity of their facilities, and numerous world-known players and professionals participated in the design. The courses are spread diversely, by the beach, further in inland, etc., all of diverse difficulty and with beautiful landscape capable of satisfying the needs of various profiles of players. The most central area is situated between Vale do Lobo, Vilamoura and Quinta do Lago and is very luxurious and best equipped for playing golf. The courses in this part represent a combination of links and fairways with cliffs, lakes and bunkers, that way providing a high standard of golf holes. When discussing Sotavento, golf courses are more level and more imaginatively designed and as such provide challenges as well as the need for using various clubs. All the golf courses prove their functionality and capabilities for all levels of players, in particular the most experienced ones through organization of international golf tournaments. This golf destination is also appropriate for beginners, considering that they can attend Golf Academies in order to start from the basics or to improve their current level of achieved golf technique. During the lessons, the best equipment is used as well as current teaching methods being taught by top quality professionals (visitPortugal, n.d.). Bearing in mind the importance of golf for the destination's economy and tourism development, the Tourism Association of Algarve decided to undertake a research to determine its economic impact. The research was conducted by PricewaterhouseCoopers (PwC). The results indicated that in 2017 alone golf was responsible in obtaining 370 million euros in tourism expenses, respectively a revenue that managed to generate approximately 16,800 jobs and a total Gross Value Added of 500 million euros. Carlos Gonçalves Luis, the president of ATA emphasized that Algarve participates with approximately $70 \%$ of total national rounds of golf per year, respectively in 2017 a total of 1,341 million rounds were played in the region which implicates its importance for tourist offer development. The results of the research also indicate that $87 \%$ of golf players visited Algarve in the past which indicates their satisfaction with the golf tourist offer to the point that it stimulated them to revisit. Their average consumption per stay amounts approximately 1,500 Euro, and they prefer in four- and five-star hotels. The majority are British (73\%) which indicates the relation to the number of air connections, respectively flights to 30 cities in the United Kingdom and Ireland. When considering Algarve as a golf tourist destination, for the respondents the most significant factors were mild climate $(79 \%)$ and quality of fields (56\%) (IR Group, 2018).

Previously presented information represent the state of tourism before it being faced with the COVID-19 pandemic, one of the greatest challenges that the world countries and their economies ever had to face. As a result of that, travel industry stopped practically overnight which resulted in numerous negative economic consequences. Until today some of the destinations started their process of recovery, but tourism is still very much faced with a large decline and it is expected that there will be long term consequence. It is hard to predict when and to what extent tourism market will recover and function normally (Ferjanić Hodak, 2020, 123). A difficult question has already taken place in the minds of analysis' and policy makers is that what will be the extent of damage done by COVID-19 in global economy (Hosain \& Rasel, 2020, 33). 
In order to be able to consider how to recover from this critical situation, Greenfee 365 booking platform (The Golf Wire, 2020) decided to conduct a large-scale survey during June and July of 2020. Over 30,000 golfers agreed to participate in the research around Europe and state their future intentions in undertaking journeys motivated by golf. The respondents stated quite clearly that golf represents a dominant motive for travel at home and in the surrounding areas. Three questions that were asked were focused on determining in which country next will they be traveling to play golf, in which part of that country and when will they be traveling to play golf. The replies were mainly divided through respondents from Germany, United Kingdom and Sweden. The majority of the respondents stated that they will not be traveling to play golf until the year 2021, and only $4 \%$ responded that they will not travel due to golf until 2022 and beyond. The results indicated that the year 2020 will be the year when domestic golf will be dominating. When observing the responses by German participants, it has been noted that $32 \%$ of them will remain in Germany to play golf, $22 \%$ expressed the interest of traveling to Austria, and $13 \%$ stated they would like to travel to Spain in 2020. The results for the respondents from the United Kingdom are higher in relation to the German respondents; nearly $50 \%$ of them stated that they will remain in the United Kingdom during 2020 to play golf. As a second choice they stated Ireland. Despite this focus on domestic golf among Europeans, 39\% of Swedish golfers stated that they will be traveling to Spain to play golf during 2020, while $33 \%$ of them will remain in Sweden to the rest of the year. When observing the future tendencies of the respondents for the year 2021, it can je justifiably stated that the golfers will be traveling again, and to the exotic destinations. 19\% of German golfers stated that they intend to travel to Spain due to golf by 2021, and $16 \%$ stated that they will continue to play in Germany. A significant number of golfers from United Kingdom decided to remain focused on domestic golf tourism, respectively $33 \%$ of them will remain to play golf in their homeland, while $22 \%$ of them intend to travel to Portugal. For Swedish golfers Spain remains a dominant golf destination; $43 \%$ of them stated their intention to travel to Spain to play golf in 2021 , and $12 \%$ stated Portugal as their preferred golf destination of choice. Previously presented findings of this survey indicate quite clearly that golfers still tend to travel due to playing golf, which indicates that it can be expected that in the future golf tourism will recover and return even stronger to the tourism scene. From the previously mentioned it is evident that golf occupies an important place in the design of the tourist product of numerous European destinations. Guided by the fact that implementation of golf in tourism influences on prolonging the tourist season, increases the utilization of tourist capacities in the destination, and has direct and indirect positive influence in all stakeholders of destination's tourist development, European destinations have been giving tremendous attention to the golf as a factor of quality of a destination's tourist product.

Croatia is a destination with a long tourist tradition, which still bases mostly its tourist offer on a traditional "sun and sea" offer despite registering positive movements in developing specific forms of tourism. Its business is still characterized by high seasonality, and the majority of total tourist turnover is achieved in the summer months. All this represents sufficient reason for undertaking new developmental activities of Croatian tourist offer based on specific forms of tourism, in this case, golf tourism which will bring numerous advantages for Croatia (reduction of seasonal 
character of business, attraction of tourists with higher purchasing power, increasing of total tourist turnover, and achieving competitiveness on the tourist market (Ivanović et al. 2011).

\section{Determing the state of golf tourism in Croatia}

Golf has a long historical tradition in Croatia. Its practice started between two World Wars, and in the beginning to twenties of the last century one of the biggest and most beautiful golf courses was built in Brijuni. In the following twenty years it became a gathering place of the European and world aristocracy and golf elite. Golf was also played in the playground in Ičići by Opatija (since 1931) as well as in the vicinity of Split. In 1929 in Maksimir in Zagreb a golf course with nine holes was open. After World War II in Croatia golf registered a strong decrease until 1990 when it was revived. In July 1992 six Croatian golf clubs established a Croatian Golf Society which became that same year the member of the European Golf Federation (Bartoluci and Čavlek, 2007, 147; Bartoluci and Čavlek, 2000). According to the current Strategy of Development of Croatian Tourism until 2020 (Ministry of Tourism, 2013), golf tourism belongs among the tourist products with an exceptional developmental perspective. Today in Croatia approximately over 1,500 people are active golf players, of which 1,000 players are registered in 18 golf clubs and four associations, members of Croatian Golf Association. Other 500 players are members of other ten clubs. However, there is a certain number of players who are active, but still haven't joined any clubs (Ministry of Tourism, 2017). Today there are total of six golf courses in Croatia where it is possible to play: Riverside in Zagreb (27 holes), Adriatik in Savudrija (18 holes) in Brijuni (18 holes), Dolina Kardinala in Krašić (18 polja) (currently out of function), St. Martin (9 holes) and Krasica, Bakar ( 9 holes). There are four centres where it is possible to practice and play golf: Split, Stobreč (6 holes), Zmajevac, Kneževi vinogradi (6 holes), Ban Jelačić, Zaprešić (3 holes) and Principovac, Ilok ( 3 holes). Exclusive practice is possible on the following playing fields: Katoro in Umag, Lanterna in Tar, Plava laguna in Poreč, Valalta in Rovinj, golf club Pula (detour in Pula), Verudela in Pula, Rabac, Omiš in Krk, Žrnovnica in Senj, Zaton in Nin, Punta Skala in Zadar, Dubrovnik in ACI Marina, Plitvice Resort, Čakovec and Samobor (Golf Tourism Croatia, 2020).

Croatia has made some moderate efforts in development of golf courses. I.e., golf was returned in Croatia and its tourist offer through renewal of the old golf course in Brijuni in 1992. Today this golf course does not satisfy basic standards of golf game, but it is extremely interesting for the visitors due to its unique beauty and preserved nature. Only 20,000 Euro was invested in the renewal of this golf course with nine holes, however, the investments were returned after several years. Tourists visit Brijuni due to golf as a primary or secondary reason to visit. Despite this golf course being non-standard, direct income can reach up to 300,000 of Croatian kuna, and costs make up 50\% of that amount. Approximately around 1,000 daily cards are being sold, and 40 seasonal ones. Other incomes are a lot higher, like hotel accommodation, food and beverage, income of the golf house, renting golf cars, etc. It has been estimated that golf can earn for Brijuni a little bit over one million of Croatian kuna per year. They do business throughout the entire year, and the majority of turnover is achieved in May, June and September (Ministry of Tourism, 2017, p. 19). Golf course Adriatic 
in Savudrija represents one of the best indicators of how golf tourism contributes to the development of Croatian tourist offer. This golf course was opened in 2009 and has been registering the growth of sold daily tickets (green fees). It earns approximately between 1 and 1,2 million euro just from golf. Costs are lower for 100 to 200 thousand of Euro than the income, which is normal for Mediterranean resorts. Guests have at their disposal high quality accommodation capacities (hotel Kempinski, tourist settlement of villas and apartments Skiper, other accommodation capacities in the vicinity, etc.,), they visit local restaurants and buy domestic products (wine, olive oil, smoked ham, cheese, etc.) and that way they achieve additional consumption of up to 2 to 3 million of euro (Ministry of Tourism, 2017, p. 20). Previously presented good examples of practice of successful development of golf tourism are in accordance with the Herak's statement (Novi List, 2019) which emphasizes that in the future Croatia must make additional efforts towards developing golf tourism, in particular since long-term forecasts have indicated quite clearly that due to the increase of tourist arrivals, opening new emitting markets, increase of travels of special interests etc., in the future tourism will continue to present one of the most significant economic branches in the world. Contemporary tourists are interested in travels motivated by specific needs, like golf tourism, and destinations with good preconditions like Croatia need to develop it. But in order to be able to do that, it is mandatory to have a clear insight how golf (tourism) is being perceived in Croatia.

A research was conducted by the Dražen Slamar in the Golf Croatia Association (2019). The goal of the research was to explore the opinion of the respondents about golf as a sport in general, as well as about it being a part of a tourist offer. The survey was conducted in the period 27th September-10th October 2019 on a sample of 118 respondents. The questionnaire contained 18 questions total, covering sociodemographic questions, as well as the respondent's attitudes. According to the gender, $60 \%$ of the respondents were male, and $40 \%$ were female. Most of the respondents belong to the age groups 31-45 (31\%) and 46-60 (31\%), followed by the age group $61+(20 \%)$ and 18-30 (18\%). A significant percentage of respondents possess a faculty degree $(68 \%)$, followed by professional degree $(15 \%)$, high school degree $(12 \%)$ and students $(5 \%)$. When asked whether they ever played golf, $51 \%$ of the respondents said yes, $28 \%$ responded no, and $21 \%$ stated no, but they would be interested to try it. When asked do they find golf attractive, $70 \%$ of the respondents stated they find it (very) attractive, $19 \%$ stated a moderate level of attractiveness of golf, while $11 \%$ of the respondents stated they do not find it attractive at all. When asked about the influence of golf on the environment, 33\% of the respondents stated they consider it being positive, $15 \%$ stated they think the influence is positive but they are not familiar with the topic, $15 \%$ consider that golf can have an influence on the environment by severe treatment of the soil, $13 \%$ consider that there is no influence on the environment, $11 \%$ stated they do not know, $6 \%$ stated that golf can influence the environment if a large quantity of forest is cut, $5 \%$ stated they consider golf having a negative influence, and $2 \%$ expressed a very negative attitude. Following the attitudes about golf tourism will be presented. When asked do they perceive golf tourism as tourism for guests of high purchasing power, the majority (49\%) stated yes, $40 \%$ stated not necessarily, and $11 \%$ said no. When asked about the golfer's consumption, respectively do they think that golf tourists spend more than holiday 
tourists, $74 \%$ of the respondents said yes, $16 \%$ stated they do not know, and $10 \%$ said no. In order to achieve success, it is important to understand the best possible way how to attract tourists. When respondents were asked what would attract them to play golf, respectively, what would destination need to offer for them to come and play golf, $83 \%$ stated that the primary motive would be golf itself, followed by gastronomic and wine offer $(60 \%)$, new experiences (47\%), socializing (43\%), wellness (36\%), and $32 \%$ due to entertainment. The majority $(74 \%)$ of the respondents stated they would be interested in trying a one-day golf tourist arrangement, $20 \%$ stated maybe and $6 \%$ stated they are not interested. When respondents who are golfers were asked how much they would be willing to spend for a weekend arrangement (two days) of playing golf with additional facilities, $51 \%$ of the respondents stated up to 1,000 of Croatian kuna, $42 \%$ would be willing to spend up to 2,000 Croatian kuna, a $8 \%$ would be interested in spending over 2,000 Croatian kuna. When the same question was asked to respondents who are non-golfers, $56 \%$ of the respondents stated they would spend up to 1,000 Croatian kuna, $33 \%$ would spend up to 2,000 Croatian kuna, and $11 \%$ would spend over 2,000 Croatian kuna. When golfers were asked how much they would be interested in spending for a seven day arrangement of playing golf with additional facilities (seven nights, five to six games of golf), $47 \%$ of respondents stated up to 5,000 Croatian kuna, $47 \%$ up to 7,000 Croatian kuna and $9 \%$ over 7,000 Croatian kuna. When non-golfers were asked the same question, 74\% stated up to 5,000 Croatian kuna, $24 \%$ up to 7,000 Croatian kuna, and 3\% over 7,000 Croatian kuna. In terms of preference when choosing a passive or active holiday, 58\% of respondents stated they prefer an active holiday, $33 \%$ a combination, while only $8 \%$ chose a passive holiday. Support of the domestic population is of extreme importance when developing tourist offer. When asked Croatia should develop golf tourism, most of the respondents responded positively $(53 \%)$ stating that Croatia needs to develop specific forms of tourism, 26\% said yes, 16\% said maybe but not with a high intensity, 3\% were not certain, and only $3 \%$ were against the development of golf tourism. Intensity of development of golf as a sport as well as the realization of golf projects represent a precondition for successful development of golf tourism. $82 \%$ of the respondents stated that the development is progressing too slow, $12 \%$ considered that it is moderately fast, $6 \%$ sufficiently fast and no respondents stated that the development and progress is very fast. The respondents who chose in the previous question the answers too slow or moderately fast were asked to state their reasons; $65 \%$ of the respondents stated complicated and insufficient law regulations, after which follow slow administration (64\%), negative perception about golf as a sport and tourist facility (60\%), avoiding bringing decisions of institutions and individuals in charge $(50 \%)$, activities of "green" and similar associations (47\%), non-professional administration (40\%), weak cooperation of investors/developers/golf professionals with the administration (35\%), media (27\%), non-professional investors and developers $(23 \%)$, hatred towards golf $(13 \%)$, and other reasons $(8 \%)$.

Previously presented information within this chapter clearly indicates that golf tourism offer of the Republic of Croatia is still pretty much far from reaching its true potential. Future success of development of competitive golf tourist offer needs to be based on the following (Ministry of Tourism, 2017, p. 28):

- Croatia as a golf destination needs to be constantly available in terms of traffic, whether by car and/or by direct flights; 
- Golf courses and practice grounds need to be of high quality and recognizable (minimum of 3 to 5 golf courses in the destination);

- Considering the importance of sustainability in development of a competitive tourist product, "green approach" is mandatory when building and maintaining golf courses;

- Golf houses and additional facilities need to be top quality;

- Quality of accommodation facilities (in the vicinity of golf courses) needs to be top quality as well with the possibility of various sorts and standards of quality (from camps to luxurious hotel resort);

- Attractiveness of the destination needs to be based on its uniqueness and recognizability, preservation of natural and social characteristics of the golf course location, as well as sense of safety and offer of facilities in the destination;

- Quality of restaurant offer is of upmost importance considering that golfers like to taste domestic food and beverages;

- Range of cultural, entertainment, sports and trade facilities in a destination;

- Travels/capacities need to be sold efficiently, in particular through specialized agencies and online;

- It is important to tend towards building an attractive destination image, in particular by generating publicity through organization of golf events (tournaments, competitions, etc.).

Based on them the authors will present some of the developmental guidelines in the following chapter.

\section{Developmental activities of golf tourism of the Republic of Croatia}

Based on the findings presented in the previous chapter, the authors present the following developmental activities (Ministry of Tourism, 2017, pp. 35-42):

- Informing the public about characteristics of golf through informationpromotion activities in order to enable for the public to understand the characteristics of golf as a sport, and how its development effects the environment, society and the economy. Particular attention needs to be given to the influence of golf on the environment and contemporary methods of its protection through presentation of best practices, presentation of economic benefits for the local community, health benefits for golf players, etc. Information and promotion activities should be focused on the media because media relations are one of the most efficient ways of formation or changing a person's perception. In terms of the activities that need to be undertaken, it is important to research the perception of golf in public due to definition of facilities of information-promotion activities and measuring its effects (determining the attitudes and information about golf in general in the public, and analysing contents and messages in media). Following it is important to analyse the examples of best practice and experiences of competing countries with developed golf tourism. Furthermore, it is important to form a strategy and goals of communication towards target groups (choosing ways of communication, designing message contents, preparing the appropriate 
material for news reporter, etc. and measuring effects of informationpromotion activities. The activities need to be conducted by the Croatian Ministry of tourism, and Tourist Board, as well as Central State office for sports, Golf association of the Republic of Croatia, golf clubs, individual experts. These activities should be funded by the Ministry of Tourism and the Tourist Board.

- Support from the state, as well as regional and local self-government for development of golf. It is necessary to position itself as a golf destination on the European map through building several Golf "clusters", and through that improve the competitive position on the tourist market. Through investments in golf projects it is possible to influence on the GDP growth as well as formation of new work places, increasing tourism income and reduction of seasonality. It is important to include the state, regional and local selfgovernment on greater level in terms of finance, organization, and legislation. Some of the activities that need to be undertaken are the following: to form a guide for investments in golf courses with detailed, relevant and reliable instructions about the process of getting all the necessary permits and receipts, conditions for obtaining the status of strategic project of state significance, etc., forming guidelines for sorting golf courses in relation to the complexity of construction permits necessary for their building, ensure for investors the credit lines according to better conditions (HABOR), more active involvement of the state in the realization of public golf courses, etc., defining the activities of tracking the conducting and control of quality of golf projects, starting the process of certification of golf courses in relation to their effect on the environment, etc. Activities should be conducted by the Ministry of Finance, Ministry of Construction and Physical Planning, Croatian Golf Association, regional and local self-government, private entrepreneurs, etc. Financing should be obtained from Ministry of Tourism of the Republic of Croatia, Central State Office for Sports, and local self-government.

- Education of administrative personnel in state and local bodies. It is necessary to remove the unnecessary (primarily administrative) barriers for building golf courses. Negative perception of golf by the public influences tremendously on developmental politics of golf in Croatia, and this politics depends on the administration which is involved in process of planning and getting necessary permits for building golf courses through state and local bodies. When interviewing the investors, representatives of state government and local self-government included in that process, as well as other stakeholders, an attitude was expressed that frequently administration is not appropriately educated about certain aspects of golf which has a negative influence on their decisions, respectively it slows the process of acquiring the necessary permits. This is the reason why the process of solving administrative and other jobs for building golf courses can last up to ten years, which is unattractive for the investors and due to that they consider the administration as the enemy of the building project. In terms of activities it is necessary to create education programs, manuals, to educate administrative personnel in state and local bodies. Activity carrier should be the Ministry of tourism of the Republic of Croatia, along with Croatian Golf Association, 
Central state office for sport, scientific and education institutions. Financing should be made by the Ministry of tourism of the Republic of Croatia.

- Formation of a project of long-term development of Golf tourism in Croatia. The goals are to achieve a balanced and sustainable development of golf tourism in Croatia, to position itself as a golf destination on the map of Europe through formation of several golf clusters, and by that to improve the competitive position on the tourist market, and through investments in golf projects to influence on the growth of GDP, formation of new work places, increasing income achieved by tourism, reduction of seasonality of Croatian tourism and increasing the life quality of domestic population. In terms of activities, it is important the document which contains the principles and concept of long-term development of golf and golf tourism, definition of criteria for locating golf courts and golf resorts, analysis and revision of locations intended for golf courses in spatial plans of the counties from the aspect of developmental concept, defining locations of interest for the state, region and local communities along with achieving consensus by involving the local community in the process of planning and formation of clusters that need to be achieved in the prescribed period, defining the model of participation of the state in realization of long-term development of golf and golf tourism (including local self-government and local entrepreneurship), estimating effects of planned development on the economy, society and the environment, forming plans of activities with deadlines and duties, and finally formation of Strategic estimate of influence of the plan on the environment. Activity carrier would be the Ministry of Tourism of the Republic of Croatia, along with Ministry of Construction and Physical Planning, Ministry of Environment protection and energetics, Central State office for sports, Croatian Golf Association, etc. Source of financing would be Ministry of Tourism of the Republic of Croatia;

- Forming eduation for the needs of golf. It is necessary, in the sense of activities, to question the possibility of establishing education for managers of courses/resorts on some of the economic/tourism faculties, to question the possibility of establishing education for leaders of maintenance of golf courses at the Faculty of Agronomy, to question the possibility of establishing the education for professional teachers of golf (PRO golf teacher) at the Faculty of Kinesiology, Croatian Olympic Academy, and to question the possibility of establishing the Golf Academy which implies appropriate Curriculums, founder and space for classes and diverse professionals who will teach the attendents. Activitiy carrier would be Ministry of Science and Education of the Republic of Croatia, Central State office for Sports, previously mentioned faculties, Croatian Golf Association, etc. Source of financing would be Ministry of tourism, Ministry of science and education, and Central State office for Sports;

- Improvement of Information basis which is of significant importance for monitoring effects, improving and development of golf tourism. It is necessary to define the group of indicators which are important for tracking, planning and developing activities of Croatian golf tourism both from the side of supply and demand, to determine the way of gathering data and responsibility carriers, formation of database, defining ways of data 
dissemination, establishing a continuous research of characteristics of demand, and to consider the possibility of establishing tracking of total economic effects of golf within the formation of Tourism Satellite Account. Activity carrier would be State Central Bureau for Statistics, along with Ministry of Tourism, Ministry of Finance, Ministry of Economy, Entrepreneurship and Crafts, Croatian Golf Association and scientific institutions. Source of financing would be State Central Bureau for Statistics and Ministry of Tourism;

- Marketing. The goals of marketing activities would be to promote Croatia and its regions as a golf destination, to increase the tourist's consumption, and to introduce green technologies and innovations in the development of offer and management. In order to do that, it is mandatory to create a marketing strategy of golf tourism (formation of a product of a golf destination and formation of a promotion plan). Activity carrier would be Croatian Tourism Board along with Ministry of Tourism, Croatian Golf Association, Tourist Boards, travel agencies and private entrepreneurs. Source of financing would be the Ministry of Tourism and Croatian Tourist Board.

It is the author's opinion that application of previously presented activities would achieve development of a competitive golf tourist offer of the Republic of Croatia.

\section{Conclusion}

The primary goal of this article was to point out on the importance and the necessity of development of golf tourism as a part of Croatian tourist offer. Through the analysis of a theoretical background, the international trends and examples of good practice the authors have managed to prove that world and european destinations have recognized the importance of golf tourism and are developing it. Following the analysis of the state of golf tourism in Croatia clearly states that significant improvements need to be made in terms of building additional top quality golf courses and offering additional top quality facilities that would accompany golf tourist offer. Presented results of the empirical research clearly indicate that significant percentage of the respondets is very much interested in trying golf, but they consider it as a tourism for guests which possess a high purchasing power, which may be considered as a barrier, which is necessary to overcome by offering services with the appropriate price. When asked what would destination need to offer them in order to visit and play golf, the majority primarily stated golf itself, but also the additional facilities like gastronomic and wine offer, socializing, wellness, and entertainment. They expressed a high interest in buying golf tourist arragements, and they would be interested in paying for it in order to achieve experience and value for money. Additional thing of interest is that $79 \%$ of the respondents consider that Croatia should most definitely develop golf tourism. However, the obstacles that they consider as the most significant problem are too slow progress of the develoment due to complicated and insufficient law regulations and administration, negative perception about golf, nonprofessionalism of the administration, etc. It is the author's opinion that the application of developmental activities would contribute in developing a competitive golf tourist offer of the Republic of Croatia. 


\section{References}

Aksu, A., Uçar, Ö. \& Kılıçarslan, D. (2016). Golf Tourism: A Research Profile and Security Perceptions in Belek, Antalya, Turkey. International Journal of Business and Social Research, 6(12), 1-12. https://doi.org/10.18533/ijbsr.v6i12.1016

Alkier, R., Milojica, V., \& Drpić, D. (2015). Promocija kao faktor ojačanja konkurentske pozicije nautičkog turizma Republike Hrvatske na turističkom tržištu. Pomorski zbornik, 49-50(1), 239-264. https://hrcak.srce.hr/138210

Bartoluci, M. \& Čavlek, N. (2000). The economic basis of the development of golf in Croatian tourism: perspectives and misconceptions (in Croatian). Acta Turistica, 12(2), 105-138.

Bartoluci, M. \& Čavlek, N. (2007). Devleopment of Golf in Croatian Tourism (in Croatian). In M. Bartoluci \& N. Čavlek (Eds.), Tourism and Sport-Aspects of Development, (pp. 147-166). Zagreb, Hrvatska: Školska knjiga

Bartoluci, M., Čorić, D. \& Jerkunica, A. (2019). Analysis of the Possibilities of Golf Tourism Development in Continental Croatia. In M. Leko Šimić \& B. Crnković (Eds.), 8th International Scientific Symposium Economy of Eastern CroatiaVision and Growth (pp. 650-662). Osijek: Faculty of Economics Osijek.

Boukas, N. \& Ziakas, V. (2014). Exploring perceptions for Cyprus as a sustainable golf destination: motivational and attitudinal orientations of golf tourists. International Journal of Sport Management and Marketing, 14(1-4), 39-70. https://doi.org/10.1504/IJSMM.2013.060639

Çuhadar, M. (2013). Development of golf tourism and golf tourism demand forecasts in Turkey: a study of Belek region. Journal of Human Sciences, 10(1), 1620-1639.

Domínguez-Gómez, J.A. \& González-Gómez, T. (2017). Analysing stakeholders' perceptions of golf-course-based tourism: A proposal for developing sustainable tourism projects, Tourism Management, 63, 135-143, https://doi.org/10.1016/j.tourman.2017.05.015.

Ersoy, A. \& Gülmez, M. (2014). A Research towards the Development of Golf Tourism in Belek Region. Journal of International Social Research, 7(34), 954-969.

Ferjanić Hodak, D. (2020). Influence of COVID-19 Pandemic on tourism market: Bibliometric and Content Analysis. In T. Baković, D. Naletina \& K. Petljak (Eds.), Trade Perspectives 2020: The interdependence of COVID-19 pandemic and international trade (pp. 123-131). Zagreb: Faculty of Economics \& Business \& Croatian Chamber of Commerce.

Golf Course Association Europe (n.d.). Golf in France, https://www.gcae.eu/golffrance/

Golf tourism Croatia (2019), Golf turizam u Hrvatskoj rezultati online ankete u 2019. godini, https://golftourismcroatia.com/ankete/

Golf tourism Croatia (n.d.), Gdje igrati, https://golftourismcroatia.com/gdje-igrati/

Hosain, M. S., \& Rasel, M. (2020). The global economic impact of COVID-19: Three possible scenarios. BizInfo (Blace) Journal of Economics, Management and Informatics, 11(1), 31-40. https://doi.org/10.5937/bizinfo2001031H 
IR GROUP (2018). Golf tourism in Algarve generated a global wealth of 500 million euros, https://www.irgroup.pt/blog/17-golf-tourism-in-algarve-generated-aglobal-wealth-of-500-million-euros

Ivanović, S., Alkier-Radnić, R. \& Jerak, T. (2011). Signifance of golf for repositioning of the Istria on the tourist market, In D. Milanović \& G. Sporiš (Eds.)., 6th International Scientific Conference on Kinesiology „Integrative power of kinesiology“ (pp. 635-638). Zagreb: Faculty of Kinesiology.

Ivanović, S., Milenkovski, A. \& Milojica, V. (2020). An Evaluation of the Current State of Sport Tourism Offer in Croatian Coastal Destinations. In M. Kolaković, T. Horvatinović, I. Turčić (Eds.). 5th Business \& Entrepreneurial Economics Conference 2020 (pp. 80-87). Zagreb: Student Business Incubator and Faculty of Economics and Business Zagreb.

Jeremić, Z., Juraković, L., Štokovac, D., Šaškin, B. \& Đulabić, D. (2010). Uvod golfa $\mathrm{u}$ turističku ponudu Istre, In S. Marić \& Z. Lončarić (Eds.). Conference Proceedings of 45th Croatian and 5th International Symposium of agronomists (pp. 263-267). Osijek: Faculty of Agriculture.

KPMG (2019). Golf Participation Report for Europe 2019 Golf Advisory Practice in EMEA, https://www.golfbenchmark.com/golf_participation_report_for_europe_2019

López-Bonilla, J.M., Reyes-Rodríguez, M.D.C. \& López-Bonilla, L.M. (2014). The Environmental Attitudes and Behaviours of European Golf Tourists, Sustainability, 10(7), 1-16. https://doi.org/10.3390/su10072214

López-Bonilla, L.M. \& López-Bonilla, J.M. (2016). From the new environmental paradigm to the brief ecological paradigm: a revised scale in golf tourism, Anatolia, 27(2), 227-236, DOI: 10.1080/13032917.2015.1100128

Ministry of Tourism (2013). Strategija razvoja hrvatskog turizma do 2020., https://mint.gov.hr/UserDocsImages/arhiva/130426-Strategija-turizam2020.pdf

Ministry of Tourism (2018). Akcijski plan razvoja golf ponude, https://mint.gov.hr/UserDocsImages/AA_2018_cdokumenti/180125_akcijski_golf.pdf.

Moital, M., Dias, N.R. \& Machado, D.F.C. (2013). A cross national study of golf tourists' satisfaction, Journal of Destination Marketing \& Management, 2(1), 39-45, https://doi.org/10.1016/j.jdmm.2013.02.003.

Novi list (2019). Ivan Herak: Golf industrija u Europi godišnje okreće 50 milijardi eura. $A$ mi spavamo već 20 godina, https://www.novilist.hr/novosti/hrvatska/ivan-herak-golf-industrija-u-europigodisnje-okrece-50-milijardi-eura-a-mi-spavamo-vec-20godina/?meta_refresh=true

R\&A. (2019). Golf Around the World. Edition 3, https://www.randa.org/ /media/files/golfdevelopment/gaw-2019-edition-3hi.ashx

Rabotić, B. (2011). Selektivni oblici turizma. Visoka turistička škola strukovnih studija Beograd.

Song, H-M., Kim, K-S., \& Yim, B.H. (2017). The mediating effect of place attachment on the relationship between golf tourism destination image and revisit intention. 
Asia Pacific Journal of Tourism Research, 22(11), 1182-1193. https://doi.org/10.1080/10941665.2017.1377740

Thanha, N.T.K., Tuana, L-A \& Nguyenb, N.D. (2021). Evaluation of factors impacting the player loyalty in golf course business, Management Science Letters, 11, 155-164. http://dx.doi.org/10.5267/j.msl.2020.8.020

The Golf Wire (2020). The Key Findings from the European Golf Travel Survey 2020, https://thegolfwire.com/european-golf-travel-survey-2020/

Visit Portugal (n.d.). Algarve - the best golfing destination, https://www.visitportugal.com/en/content/algarve-best-golfing-destination

Visit Portugal (n.d.). Golf, https://www.visitportugal.com/en/experiencias/golfe

World Tourism Organization (2019). International Tourism Highlights 2019 Edition, https://doi.org/10.18111/9789284421152

yourgolftravel (n.d.). Golf Breaks in France, https://www.yourgolftravel.com/golfholidays/france

Rad je primljen: 15.12.2020; Prihvaćen: 24.12.2020.

Received: 15 December, 2020; Accepted: 24 December, 2020 
